\title{
Internal Control Techniques and Fraud Mitigation in Nigerian
} Banks

\author{
Dr Okonkwo Ikeotuonye Victor and EzegbuNnennaLinda \\ Department of Banking and Finance, Faculty of Management Sciences NnamdiAzikiwe University, Awka
}

\begin{abstract}
Frauds are experiences Banks and other organizations have to mitigate. Depravity of mankind could be reason for increasing tendency to fraudulent acts. The banks and regulatory authorities have proposed and allowed internal control measures to check the practice of bank fraudseven in Nigeria. But the effectiveness of any internal control system is dependent on how fluid the system interacts with itself and how embedded it is into the organization's business processes. Using a survey method, this work examined how the internal control systems in the branches of the studied banks: Guaranteed Trust Bank Plc and Fidelity Bank Plc have aided in combating or preventing fraud in Nigerian banks. Among the findings were that: the internal control techniques employed by banks in checking fraud have not been very effective; and the branch managers were the dominant perpetrators of fraud in the banks. We recommend among other things that all banks should establish work ethics unit; reduce excessive confidence in any bank staff; and leadership by example should be the watch word of all bank mangers.
\end{abstract}

Keywords:Internal control, Fraud, Banking, and Bank fraud

\section{Introduction}

Banks are prominent in mobilizing savings in any economic system by offering savings facilities to the public. Some of the functions of the banks include the acceptance of deposits from the public and channeling such deposits to the deficit sectors of the economy that are in need of investible funds. These two related and dependent functions bring the bank face to face with the public who come to obtain their services. This implies that banks attend to a large number of customers who they may or not, most of the time, personally know or whose identity the banks may not immediately known. Banks are supposedly to make efforts to know their customers, given that they may hardly know the remote intentions of their numerous customers: whom either have honest or fraudulent intentions.

Bank fraud cases are usually distinguished from outright bank robbery as they rely on the use of deception and confidence tricks rather than the threat or use of violence. Bank fraud cases come in many different forms including several types of cheque fraud, identity theft and embezzlement and document fraud.

According to NDIC (Nigeria Deposit Insurance Corporation), Deposit money banks (DMB) lost a total sum of 25.61 billion naira to fraud and forgeries within the banking system in 2014. This amount represented an increase of 3.81 billion naira or $17.5 \%$ compared to 21.80 billion lost in the previous year (2013). Also, a total of 10,612 fraud cases were recorded in 2014 compared with 3,786 cases in 2013, representing an increase of $182.77 \%$.

Fraud has become an unfortunate staple in Nigerian's International reputation. It is really eating deep into the Nigerian banking system and any bank with a weak Internal Control system is dangerously exposed to bank fraud (Adeduro, 1998).

Fraudulent acts has necessitated Internal Controls: (whole system of control, financial and otherwise established by management in order to carry on the business of the enterprises in an orderly and efficient manner) in entities including the Deposit money banks. Frauds have led to the loss of large amount of money in the economy as a whole and in the banking industry in particular. The acts have contributed significantly to the financial distress of some banks and the poor performance of the others.

Despite the fact that writers and professionals have proffered solutions on this issue of fraud, fraudulent activities in the banking industry has consistently continued. Substantial amount of money has been committed to check the occurrence. Yet, it seems that the integrity of the employees and management of the concerned banks are questionable. How it is that fraud rate is on increase in spite of improving internal control systems in the Banks. The broad objective of this study is to examine the extent the internal control techniques have checked the practice of bank fraud in Nigeria. The specific objectives were: identifying the dominant perpetrators of fraud in banks; examining efficiency of the internal control techniques in banks; and studying the effectiveness of the preventive measures aimed at mitigating fraud challenges in banks. We hypothesized that: Branch managers are not significant perpetrators of fraud in banks; the internal control techniques employed by the banks in checking fraud have not been efficient; the preventive measures on fraud mitigation have not been effective. 
This work is further arranged in sections: conceptual framework; theoretical framework; empirical review of related literature; research methodology; data presentation and analysis; summary of findings, conclusion and recommendations.

\section{Conceptual Framework}

Fraud is the act of depriving a person dishonestly of something, which such an individual would or might be entitled to. It is an act of deception which is deliberately practiced in order to gain unlawful advantage. Therefore, for any action to constitute fraud there must be a dishonest intention to benefit (on the part of the perpetrator) at the detriment of another person or an organization (Eseoghene, 2010). Adeleke (1996) stated that fraud means an act or cause of deception deliberately practiced to gain unlawful or unfair advantage, such deception directed to the detriment of another. Benjamin (2001) stated that fraud is simply conscience and premeditated action taken by a person or group of people to the truth or fact with a view of deriving selfish personal monetary gain. It involves the use of deceit and trick to forge or falsify document and signature in order to steal.

Fraud can be seen as the intentional misrepresentation, concealment or omission of the truth for the purpose of deception or manipulation to the financial detriment of an individual or an organization (a bank) which also include embezzlement, theft or any attempt to steal or unlawfully obtain or misuse the asset of the bank (Mahdi \&Zhila, 2008). There is a general consensus amongst criminologists that fraud is caused by three elements: "WOE" (Gold, 2009). For any fraud to occur, there must be a "will to commit" the fraud, and if the "opportunity to commit" is available, then there will be an "exit or escape route" from relevant sections or institutions that are against fraud or related deviant behaviour.

Bank fraud could be taken to deprive the bank of its goodwill as well as outside parties to deprive the bank of assets, largely in the form of cash and instruments representing cash. This includes the acts that range from misrepresentation or distortion of financial statement by top management to outright theft of cash by cashier and others such as armed robbers, to their advantage. Asukwo (1999) and Idowu (2009) identified some of the immediate and remote causes of fraud to include: Poor Internal control; Poor Book-Keeping; Greed; Inadequate Training and Re-training.

Internal control involves the control environment and control procedure, all the policy and procedure adopted by the directors and management of an entity to assist in achieving their objectives including the safeguarding of assets, the prevention and detection of fraud and error as well as the completeness and accuracy of records, with the timely preparation of reliable financial information (Benjamin, 2001).

It is necessary that every bank must have an Internal audit department to ensure that accounting systems provide an efficient means of recording and reporting financial transactions, providing management information and protecting the company's asset from fraud and misappropriation (Achibong, 1993). One of the most effective systems for detecting fraud is Internal Control, which is a system by definition, operating in the same environment as fraud itself and serving as an effective, formidable adversary to the fraud scheme (Meshane, 2007).

A system of strong Internal Control can help to ensure that the goals and objectives of a banking organization will be met, that the bank will achieve long firm profitability target and maintain reliable financial and managerial reports by entities. Such a system can help to ensure that the bank will comply with laws and regulations as well as policies, plans, internal rules and procedures to decrease the right of the expected losses or damages to the bank's reputation. The cost of fraud to a business is difficult to estimate because not all fraud and abuse is discovered, not all uncovered fraud is reported, civil or criminal action is not always pursued.

\section{Theoretical Framework}

There are different ways of which authorities have classified fraud depending on their perspectives and the criteria used. Fraud has been classified according to management and employee's fraud; the nature and perpetrator (i.e. whether the fraudster is one of the entire staff or involves outsiders; and whether the staff fraudsters are in top management position or non-management position). The formercan be divided into: "internal, external and mixed fraud" while the later according to Nwankwo (1991) gives rise to: "management and employee fraud." According to Jenfa (1991), internal fraud consists of the following classes: Unofficial borrowing; over invoicing; unauthorizedstamps; fictitious transactions; fraudulent use of document; Cash on hand converted to personal use; premature writing off of assets; Ghost workers; and figures falsification.

There are three types of fraud committed wholly by persons and organizations external to the bank, namely, Over Invoicing;Advance fee fraud say by Schemes ostensibly for the disbursement of money for mills, Contract frauds, purchase of real estates and transfer of funds; Loan Fraud; Mixed Fraud; Management Fraud including top management level staffs that are aimed largely at deceiving the shareholders and to a considerate extent, auditors and the regulatory authorities through deliberate presentation of false financial statement (Jat, 1992); Employee Fraud(examples of employee frauds are the conversions of cash or other assets of the 
employer to the fraudster's immediate benefit. Like their management counterpart, quite a number of employee's fraudulent acts occur after having gained a position of trust and responsibility. A considerable higher proportion of bank frauds are usually committed by employees in non-management positions majority of who are cashiers, clerks, and accountants(Holtfreter, 2004).

The consequences of successful fraudulent practices include: Denial to the genuine owners of their assets, property and money. Entire loss in some instance goes to the bank. The bank staff that are implicated sometimes lose their jobs. The banks mostly reimburse the customer the funds stolen where large amounts are involved, the reputation of the bank could be in jeopardy, and customer's confidence in the bank will be shaken (Ekechi, 1990). Other consequences are: Long queues, delays and frustration. Every document is subjected to double and triple scrutiny, this is why banking services are declining in quality as no one can be trusted, neither customers nor staff (Sani, 2002).

The adverse effect of police and management enquiries create an atmosphere of distrust and disruption of normal workflow. Staff are frightened of normal work decisions and processing normal work for fear of being implicated in a transaction. It is still the customer who suffers during the description of normal workflow for they have to wait for long periods (Chizea, 1991).

According to Udegbunam(1998) causes of bank fraud can be classified into institutional and environmental factors. Institutional Factorsare factors that we can trace to the internal environment of the organization. They are, to a great factor within the control of the management of the bank. Examples are poor information technology and data base management; Weak accounting and internal control system; Inadequate supervision of subordinates; Disregard for "know your customer" rule; and poor book keeping (Ojo, 2008).

Environment Factorsare those that can be traced to the immediate and remote environment of the bank. Several social issues encourage people to fall into temptation and thus join the large army of fraudulent individuals in the society. Such factors include but not limited to the following:Honesty in offices or public places are no longer encouraged, on the contrary, such people are often despised and regarded as slow, foolish, and stupid and not knowing how to utilize the opportunities at their disposal to make quick wealth; Much premium is placed on the accumulation of raw wealth in our society without sparing any thought about the source of that wealth. In fact, only a handful of parents care to ask their children or wards where they get the new books, dresses, bags or shoes that they bring home from schools; The dispensing of chieftaincy title and similar honours have become highly skewed in favour of the rich and those who pull the levels of power, even among this category of people, the highest bidders are also the front runners and Stiff competition in the banking industry which said many banks engaging in fraud so as to meet up in terms of liquidity and profitability.

There are many definitions of internal control as it affects the various constituencies of an organization in various ways and at different levels of aggregation.Under the Committee of Sponsoring Organizations (COSO), Internal Control is broadly defined as a process affected by an entity's board of directors, management and other personnel designed to provide reasonable assurance regarding the achievement of objectives in the following categories:Effectiveness and efficiency of operation; Reliability of financial reporting; and Compliance with laws and regulations.According to Millichamp (2002) Internal Control system is defined as the whole system of controls, financial and otherwise, established by the management in order to carry on the business of safe-guarding the assets and secure as far as possible the completeness and accuracy of the records.

Hevesi (2005) also defined Internal Control as the integration of activities, plans, attitudes, policies and efforts of an organization working together to provide reasonable assurance that the organization will achieve its objectives and mission. The main objective of Internal Controls include to be the assurance that organizational resources will be put to economic, efficient and effective use in order to achieve the objectives for which the organization was set up.

Millichamp (2002) puts the types of Internal Control as: safeguarding assets, separation of duties, supervision, verification, approval and authorization, documentation and reporting. However, many others authors such as Lousteau (2006)of the State University of New York and DiNapoli (2005) have agreed that the types of Internal Control includes: directive controls, preventive controls, compensating controls, detective controls and corrective actions.Directive controls relate to policies put in place by top management to promote compliance with independent rules. To ensure compliance with directive controls, a clear consistent message from management that policies and procedures are important and permeate the organization. They provide evidence that a loss has occurred but do not prevent a loss from occurring. Examples of directive controls are reviews, analysis, reconciliation and audits (Singleton, 2006).

Preventing controls relate to measures taken by a firm to deter non-compliance with policies and procedures. They are proactive controls that help to prevent a loss. Examples of preventive controls are separation of duties, proper authorization, adequate documentation and physical control over assets (Lousteau, 2006). 
Compensating controls are intended to make up for a lack of control elsewhere in the system. For example, firms with an electronic database could maintain a hard copy of the client list in the office library. Such a list would compensate for downtime in electronic systems and difficulty locating client names in an electronic system. The list would have to be reprinted from time to time to add new clients and delist obsolesce clients existing in hard copies.

Detective controls are aimed at uncovering problems after they have occurred. Although necessary in a good internal control system, detection of independence violation after the facts is less desirable than prevention in the first place. Detective controls rarely work well as a deterrent in the absence of severe penalties (Lousteau, 2006). Everyone in an organization has responsibility for internal control: Management; Board of directors; Internal Auditors; and Other personnel (Ola, 2001; Izedonmi, 2000; and Aderibigbe, 1999).

The effectiveness of an internal control system is dependent on how fluid the system interacts with itself and how embedded it is into the organizations business processes. For an internal control system to be effective, and provide needed assurance to the management, there should be some agent of effectiveness. These are a vibrant board, which does not want to be informed but a board that understands the business and questions the status quo, and an effective, independent control unit (Thornton, 2009).

Internal control is a process, but its effectiveness is a state or a condition at point of process. Therefore, it is important for management and the board to evaluate and assess the effectiveness of the internal control system periodically (Hermanson, Smith \& Stephens, 2012).According to COSO (Committee of Sponsoring Organization) (1992), an internal control system can be judged to be effective on the high level if the board of directors and management have reasonable assurance that; they understand the extent to which the entity's operations objectives are being achieved, published financial statements are being prepared reliably and applicable laws and regulations are being complied with.

An internal control framework that places too much emphasis on detailed explanation of the different components of the system and methods for their design but ignores details on how each of the components can be measured to assess their effectiveness is a deficient control system (Amudo\&Inanga, 2009). The effectiveness of an internal control system is a function of the workings of the five components of the system which are control environment, risk assessment, control activities, information and communication, and monitoring. Consequently, assessing effectiveness of internal controls must be done in relation to the components of internal control. Judging whether an Internal Control system of an organization is effective or not, is a subjective verdict resulting from the assessment of the workings of the five components of internal control system across the entire organization (COSO, internal control-integrated Framework, 2011).

There are three basic arguments for not implementing measure to ensure effective internal controls. These according to Ewa and Udoayang(2012) are: there is not enough staff to have adequate segregation of duties; ut is too expensive; and the employees are trusted and controls are not necessary. These arguments represent pitfalls to unsuspecting management. Each argument is in itself a problem that needs to be resolved.Ewa and Udoayang (2012) observed:

$>$ The problem of not having enough staff or other resources should be discussed with your supervisor. In most cases, compensating controls can be implemented in situations where one person has to do all of the business-related transactions for a department.

$>$ If implementing a recommended control seems too expensive, be sure to consider the full cost of fraud that could occur because of the missing control. In addition to any funds that may be lost, consider the cost of time that would have been spent by the department during the time of an investigation of the matter and the cost of hiring a new employee. Fraud is always expensive and the prevention of fraud is worth the cost.

$>$ Finally, consider the issue of trust. Most employees are trustworthy and responsible, which is an important factor in employee relations and departmental operations. However, it is also the responsibility of administrators to remain objective. Experience shows that it is often the most trusted employees that are involved in committing frauds.

According to the COSO (1994) framework, Internal Control system consists of interrelated components that provide the foundation for fraud detection. These basic components are related to operational effectiveness and efficiency, reliable and financial reporting and ensuring regularity. The five basic components are: fostering a favourable control environment, conducting risk assessment, designing and implementing control activities, providing for effective information and communication, and conducting on-going monitoring of the effectiveness of control related policies.

The overall success of a system of Internal Control is dependent on how effective each of these elements functions and how well they are coordinated and integrated with each other (DiNapoli, 2008).

- Control Environment: This refers to all factors which are effective in determining increasing or decreasing the effectiveness of policies, procedures and methods specific to a process. Control environment stands out with the basic understanding adopted by senior management of the corporation to control the organization, its attitude towards problems and approach to solving problems and their perspective of the 
importance of moral values. The control environment sets the tone for the organization. This means that it provides discipline and structure for the whole system. According to Kaval (2005), control environment can be perceived as a consciousness of the senior management of the corporation to control the organization and its employees.

- Risk Assessment: This is the identification of factors or conditions that threaten the achievement of an entity's objectives and goals. It is the identification of analysis of potential errors and implements control, policies and procedures in order to reveal those errors and prevent them. Because internal control is a dynamic system (economic and operating conditions are continuously changing), mechanisms of risk assessment are also subject to changes and adjustment. Proper setting of objectives is a necessary precondition to effective risk assessment. Risk assessment looks at both internal and external threat. An organization basically establishes an early warning system to determine remote risks or risks with lowprobability, and take the necessary actions to remove and minimize such risks (Frazier et al., 1996).

- Control Activities: Control activities refer to the policies and procedures designed by an organization to ensure management directives are carried out. They include a range of activities such as "approvals, authorizations, verifications, reconciliations, reviews of operating performance, security of assets, and segregation of duties." This is only possible if the management information system and its sub-systems are arranged in a disciplined and responsive manner. Control activities are the most visible element of internal control and arguably the most important in preventing wrong actions from occurring (Arens\&Lobbecke, 1997).

- Information and Communication: Information and communication can reduce the risk of fraud in two ways. First, the possibility of fraud concealment is reduced by means of the integrity and the accuracy of information. To put it differently, a person who commits a fraud can't have the opportunity of hiding it for a long time. Secondly, an open and effective communication fostered in an organization, helps in detecting the possibility of fraud in advance (Cendrowski et al, 2007, p.128). The executive summary to COSO states, "Pertinent information must be identified, captured and communicated in a form and timeframe that enables people to carry out their responsibilities. Information systems produce reports containing operational, financial and compliance-related information that makes it possible to run and control the business".

- Monitoring: Monitoring determines whether or not policies and procedures designed and implemented by management are being conducted effectively by employees. Monitoring also helps ensure that significant control deficiencies are identified timely and rectified. Monitoring internal control requires a process. This process assesses the quality of internal control in course of time (Frazier et al, 1996, p.72). Monitoring can occur through self-assessments, external audits or through direct testing of a control. By monitoring, internal control activities are constantly kept under surveillance and their performance is assessed.

\section{Empirical Review Of Related Literature}

Changsha (2010), studied the importance of Internal Control and its effectiveness to achieving organizational goal. Applying regression analysis on the experience data of 200 manufacturing listed companies in 2009, the work showed significant relationship between the value of the enterprise and Internal Control; and combining Internal Control and information technology showed that internal control plays positive role to achieving company's goal and improving enterprise value.

Adedoyin (2013) studied the Internal Control measures and the detection of and prevention of fraud in banks. Using participants from the Main Street Bank Plc Aba branch in Nigeria and applying descriptive method showed that Internal Control system was significant in detection and prevention of fraud in banks in Nigeria.

Ademola (2010) studied the effect of internal control system in Nigeria public sector; a study of the Nigerian National Petroleum Corporation. Using chi square to test the hypotheses, showed that understanding the Internal Control techniques by both the management and the low level employees helps to reduce embezzlement and fraud in the corporation.

Uhuru (2008) studied the effect of internal control on financial performance manufacturing firms in Kenya. The population of the study was 65 manufacturing firms registered by Ministry of Industrialization in Kenya. The sample of 20 firms were drawn using stratified random sampling technique. The findings revealed that most manufacturing firms had a control environment as one of the functionality of Internal Control of the organization that greatly impacts on the financial performance of the firm.

Ewa and Udoayang (2012) carried out a study to establish the impact of internal control design on banks' ability to investigate staff fraud and staff lifestyle and fraud detection in Nigeria. Data were collected from 13 Nigerian banks using a four point likert scale questionnaire. The study found that internal control design influences staff attitude towards fraud such that a strong internal control mechanism is deterrence to staff fraud while a weak one exposes the system to fraud and creates opportunity for staff to commit fraud. 
Wee Goh (2009) studied 208 firms on audit committees, board of directors and remediation of material weaknesses in internal control. He measured the effectiveness of the audit committee by its independence, financial expertise, size and meeting frequency and the effectiveness of the board by its independence, size and meeting frequency and by the duality of the chief executive officer (CEO) and chair positions (CEO duality).He also examined other factors that can affect a firm's timeliness in the remediation of material weaknesses such as the severity of material weaknesses, firm's profitability and so on. He found out that the portion of audit committee members with financial expertise is positively associated with firms' timeliness in the remediation of material weaknesses. Secondly, that a more independent board is less susceptible to the undue influence of management and more likely to exert pressure on management to remediate material weakness.

Using the analytical approach and focusing on control activities and monitoring, Barra (2010) investigated the effect of penalties and other internal controls on employee's propensity to be fraudulent. Data were collected from both managerial and non-managerial employees. The result showed that the presence of the control activities, separation of duties, increases the cost of committing fraud. Thus the benefit from committing fraud has to outweigh the cost in an environment of segregated duties for an employee to commit fraud. Further, it was established that the segregation of duties is a 'least-cost' fraud deterrent for non-managerial employees, maximum penalties are the 'least cost' fraud disincentives. The result suggest the effectiveness of preventive control activities such as segregation of duties is dependent on detective control. Bank fraud seriously endangers the organizational growth of the bank as it leads to bank distress. This is because fraud reduces the deposits of depositors and ultimately leads to the erosion of the capital base of banks. The cost of fraud is also usually difficult to eliminate because not all frauds are discovered.Thus the need for a very effective internal controls system so that cases of fraud can be reduced if not eliminated so as to continue to gain customers goodwill and stimulate their client's confidence all the time.

\section{Research Methodology}

This study applied survey method. Questionnaires were administered to the participants who were mainly drawn from bank staff (Desk Cashiers, Accounts Officers, Loan Officers, Bank Manager, Programmers, Trust Officers, Marketers, and Internal Auditors) and bank customers (Savings and current account holders) of Guaranteed Trust Bank (GTB) Okpara Avenue Branch and Garriki branch Enugu in Enugu State; and Fidelity Bank, Awka Express and Zik's Avenue Branch in Anambra State. The total number of staff of selected banks (Guaranty Trust Bank and Fidelity bank, Okpara Avenue branch and Awkabranch) were 87 with 433 customers (GTB: 225 and Fidelity Bank: 208). Using Taro Yamani formula, the sample size of 226was determined. Using bowler formula the proportions of the sample size were also determined.

The data obtained were presented using tables and according to objectives. The data were also analyzed using descriptive statistics, expected frequency response and Likert scale ranking. The Likert scales are represented as follows:Very high -5 points; High -4 points; Low -3 points; Very low -2 points; and Undecided - 1 point. Each hypothesis was tested using Chi-Square statistic at $5 \%$ level of significance. The formula is

$X^{2}=\left(\underline{f}_{0}-\underline{f}_{\underline{e}}\right)^{2}$

fe

Where, $\mathrm{X}^{2}=$ Chi-Square

$\mathrm{f}_{\mathrm{o}}=$ Observed frequency

$\mathrm{f}_{\mathrm{e}}=$ Expected frequency

Decision Rule: If the calculated Chi-Square value is greater than critical table value, we reject the null hypothesis and accept the alternative and vice-versa.

Data Presentation and Analysis

The bio data of the participants were shown in Table 1.

Table 1: Bio-Data of Participants

\begin{tabular}{|l|l|l|l|l|l|}
\hline & Items & Frequency & \% & Valid \% & Cumulative \% \\
\hline & Participants: & & & & \\
\hline & Bank staff & 83 & 36.7 & 36.7 & 36.7 \\
\hline Bank customer & 143 & 63.3 & 63.3 & 100.0 \\
\hline & Participants experience: & & & & \\
\hline & Less than 5 years & 35 & 15.5 & 15.5 & 15.5 \\
\hline & 5 to 10years & 85 & 37.6 & 37.6 & 53.1 \\
\hline & Above 10years & 106 & 46.9 & 46.9 & 100.0 \\
\hline & & & & \\
\hline & Gender: & & & & \\
\hline & Male & 107 & 47.3 & 47.3 & 47.3 \\
\hline & Female & 119 & 52.7 & 52.7 & 100.0 \\
\hline
\end{tabular}




\begin{tabular}{|l|l|l|l|l|l|}
\hline & Educational attainment: & & & & \\
\hline & Primary education level & 14 & 6.2 & 6.2 & 6.2 \\
\hline & Post Primary education level & 37 & 16.4 & 16.4 & 22.6 \\
\hline & Post-secondary education level & 58 & 25.7 & 25.7 & 48.2 \\
\hline & Tertiary education level & 117 & 51.8 & 51.8 & 100.0 \\
\hline
\end{tabular}

Source: Field Survey, 2015

From the table 1, it can be observed that $85.5 \%$ of the participants have had banking experience of above five years; the male participants were $47.3 \%$ and the female participants were $52.7 \%$; in terms of educational attainment $93.8 \%$ of the participants had at least post primary education. The bio data generally indicated significant banking experience, high literacy level of the participants, and gender sensitive representation. The table 2 displayed the distribution on the dominant perpetrators of fraud in the banks.

Table2: Mean score distribution of perpetrators of fraud in banks

\begin{tabular}{|l|l|l|l|l|l|l|l|l|}
\hline CATEGORIES & VH & H & L & VL & UND & T.S & M.S & RMK \\
\hline Desk cashiers & - & 89 & 68 & 23 & 46 & 652 & 2.88 & $3^{\text {rd }}$ \\
\hline Account officers & 23 & 22 & 68 & 23 & 90 & 543 & 2.40 & $5^{\text {th }}$ \\
\hline Loan officers & - & 45 & 67 & 68 & 46 & 563 & 2.49 & $4^{\text {th }}$ \\
\hline Branch managers & 90 & 45 & 23 & - & 68 & 767 & 3.39 & $1^{\text {st }}$ \\
\hline Programmers & - & - & 67 & 113 & 46 & 473 & 2.09 & $7^{\text {th }}$ \\
\hline Internal control officers & - & - & 45 & 113 & 68 & 429 & 1.90 & $8^{\text {th }}$ \\
\hline Marketers & 23 & 68 & 67 & 45 & 23 & 701 & 3.10 & $2^{\text {nd }}$ \\
\hline Internal auditors & - & - & 67 & 136 & 23 & 496 & 2.19 & $6^{\text {th }}$ \\
\hline
\end{tabular}

Source: Field Survey, 2015

From table 2, it was observed that the branch managers were rated high as per perpetrators of fraud by the respondents with a mean score of 3.39; followed by the marketers and desk officers that attracted mean scores of 3.10 and 2.88 respectively.Others like programmers and internal control officers rate low.

From the Table 3 we sought to assess the effectiveness of the control techniques used to combat fraud in banks.

Table 3: Distributions on effectiveness of internal control techniques in banks

\begin{tabular}{|l|l|l|l|l|l|l|l|l|}
\hline CONTROL TECHNIQUES & V.H & $\mathbf{H}$ & $\mathbf{L}$ & $\mathbf{V L}$ & $\mathbf{U N D}$ & TS & MS & RMK \\
\hline Direct supervision and observation & 76 & 120 & 30 & - & - & 950 & 4.20 & $1^{\text {st }}$ \\
\hline Direct supervision and observation & 60 & 121 & 45 & - & - & 919 & 4.07 & $2^{\text {nd }}$ \\
\hline Reconcile agency bank accounts every month & - & 120 & 76 & 30 & - & 768 & 3.40 & $4^{\text {th }}$ \\
\hline Verify all charges made to credit cards or accounts & - & 105 & 60 & 61 & - & 772 & 3.19 & $7^{\text {th }}$ \\
\hline $\begin{array}{l}\text { Providing board of directors insight of agency operators } \\
\text { and management }\end{array}$ & - & 105 & 121 & - & - & 783 & 3.46 & $3^{\text {rd }}$ \\
\hline $\begin{array}{l}\text { Ensure that agency assets are used only for official } \\
\text { business }\end{array}$ & - & 75 & 121 & 30 & - & 723 & 3.21 & $5^{\text {th }}$ \\
\hline $\begin{array}{l}\text { Requiring independent auditor to cross examine annual } \\
\text { financial statements }\end{array}$ & - & - & 60 & - & 166 & 346 & 1.53 & $9^{\text {th }}$ \\
\hline Educating employees regularly on bank fraud issues & - & 40 & - & 166 & 20 & 512 & 2.26 & $8^{\text {th }}$ \\
\hline Separate purchasing functions from payable functions & - & 75 & 121 & 30 & - & 723 & 3.20 & $6^{\text {th }}$ \\
\hline Delegating authorities to subordinates & 15 & 120 & 30 & 61 & - & 767 & 3.40 & $4^{\text {th }}$ \\
\hline
\end{tabular}

\section{Source: Field Survey, 2015}

From the Table 3, it was observed that the respondents were of the opinion that many of the control techniques identified for study were effective in mitigating fraudulent practice but for Requiring the independent auditor to cross examine annual financial statementsand educating employees regularly on bank fraud issues. The most effective control techniques were: Direct supervision and observation; Direct supervision and observations; and providing board of directors insight of agency operators and management.

Table 4, depicted opinions of the participants on the usefulness of the control measures in mitigating fraudulent acts.

Table 4: Distribution on usefulness of the measures to check fraud in banks

\begin{tabular}{|l|l|l|l|l|l|l|l|l|l|l|}
\hline MEASURES & VH & H & L & VL & UND & TS & MS & RMK \\
\hline Conducting periodic surprise visit and review of procedures & 90 & 136 & - & - & - & 994 & 4.39 & $1^{\text {st }}$ \\
\hline Use of strong anti-virus and fire walls to prevent hacking & - & - & 95 & 63 & 68 & 479 & 2.12 & $10^{\text {th }}$ \\
\hline $\begin{array}{l}\text { Constant enlightenment of customers on how to secure their } \\
\text { accounts }\end{array}$ & - & 68 & 22 & - & 136 & 474 & 2.09 & $9^{\text {th }}$ \\
\hline Periodic rotation of staff & - & 71 & 135 & - & 20 & 709 & 3.13 & $5^{\text {th }}$ \\
\hline $\begin{array}{l}\text { Setting up of reporting system and making employees aware of } \\
\text { it }\end{array}$ & 68 & 158 & - & - & - & 972 & 4.30 & $3^{\text {rd }}$ \\
\hline Ensuring appropriate security over signature plates or cards & - & 136 & 22 & - & 68 & 678 & 3.0 & $7^{\text {th }}$ \\
\hline
\end{tabular}


Internal Control Techniques And Fraud Mitigation in Nigerian Banks

\begin{tabular}{|l|l|l|l|l|l|l|l|l|}
\hline Requiring additional review process for all cheques & 4 & 69 & 136 & - & 17 & 721 & 3.19 & $4^{\text {th }}$ \\
\hline Requiring two party authorization on release of all files & 139 & 65 & - & - & 22 & 977 & 4.32 & $2^{\text {nd }}$ \\
\hline $\begin{array}{l}\text { Ensure segregation of duties among staff in initiating, } \\
\text { authorizing, signing and payments }\end{array}$ & - & 90 & 68 & 68 & - & 700 & 3.09 & $6^{\text {th }}$ \\
\hline Review of all accounts at least annually & - & 90 & 68 & - & 68 & 632 & 2.79 & $8^{\text {th }}$ \\
\hline
\end{tabular}

Source: Field Survey, 2015.

From table 4, it was observed thatthe respondents were of the view that the dominant useful measures of checking fraud were: conducting periodic surprise visit and review of procedures; requiring two party authorization on release of all files; requiring additional review process for all cheques; setting up of reporting system and making employees aware of it; and periodic rotation of staff. Other measures considered of value addition in checking fraud were: ensure segregation of duties among staff in initiating, authorizing, signing and payments; and Ensuring appropriate security over signature plates or cards. The measures considered of less value in check fraud by the participants were: review of all accounts at least annually; and constant enlightenment of customers on how to secure their accounts.

In the test of the hypotheses, we stated in Hypothesis one that: $\mathrm{H}_{0}$ : Branch managers are not significant perpetrators of fraud in banks. Table 5 showed the contingency table using the chi square formula.

Table 5: Contingency table for hypothesis one

Source: Extracted and computed from Table 2

\begin{tabular}{|l|l|l|l|}
\hline $\mathbf{O}$ & $\mathbf{E}$ & $\mathbf{O}-\mathbf{E}$ & $(\mathbf{O}-\mathbf{E})^{2} / \mathbf{E}$ \\
\hline 90 & 45.2 & 44.8 & 44.4 \\
\hline 45 & 45.2 & -0.2 & 0.00 \\
\hline 23 & 45.2 & -22.2 & 10.90 \\
\hline- & 45.2 & -45.2 & 45.2 \\
\hline 68 & 45.2 & 22.8 & 11.50 \\
\hline & & & 112 \\
\hline
\end{tabular}

Where, $\mathrm{fe}=226 / 5 \quad=\quad 45.2$

Degree of freedom: $(5-1)(2-1)=(4)(1)=4$

Tabulated value is 9.48 and the calculated value is 112 .

Therefore, since the calculated chi-square is greater than the tabulated value, we reject the null hypothesis which says that branch managers are not significant perpetrators of bank fraud and accept the alternative. This finding agrees with Egbobor (2004) where he quotes the research report of the Economic and Financial Crimes Commission (EFCC) showing that top management staff are responsible for the majority of bank fraud cases that were reported to the Commission.

The hypothesis two stated that: Ho: the internal control techniques employed by the banks in checking fraud have not been effective. And, Table 6 showed the contingency table.

Table 6: Contingency table for hypothesis two

\begin{tabular}{|l|l|l|l|}
\hline $\mathbf{O}$ & $\mathbf{E}$ & $\mathbf{O}-\mathbf{E}$ & $(\mathbf{O}-\mathbf{E})^{2} / \mathbf{E}$ \\
\hline 4.20 & 3.2 & 1 & 0.31 \\
\hline 4.07 & 3.2 & 0.87 & 0.24 \\
\hline 3.40 & 3.2 & 0.2 & 0.01 \\
\hline 3.19 & 3.2 & -0.01 & 0.00 \\
\hline 3.46 & 3.2 & 0.26 & 0.02 \\
\hline 3.21 & 3.2 & 0.01 & 0.00 \\
\hline 1.53 & 3.2 & -1.67 & 0.87 \\
\hline 2.26 & 3.2 & -0.94 & 0.28 \\
\hline 3.20 & 3.2 & 0 & 0 \\
\hline 3.40 & 3.2 & 0.2 & 0.01 \\
\hline & & & $\mathbf{1 . 7 5}$ \\
\hline
\end{tabular}

Source: Extracted and computed from table 3

Where, $\mathrm{fe}=31.92 / 10=3.2$

Degree of freedom $=(10-1)(2-1)=(9)(1)=9$

Tabulated value is 16.919 and the calculated value is 1.75 .

Therefore, since the tabulated value is greater than the calculated value, we accept the null hypothesis which says that the internal control techniques employed by banks in checking fraud have not been generally effective.

The hypothesis three stated that: $\mathrm{H}_{\mathbf{0}}$ : the preventive measures on fraud mitigation have not been effective. Table 7 showed the contingency table using the chi square formula.

Table 7: Contingency table for hypothesis three 


\begin{tabular}{|l|l|l|l|}
\hline $\mathbf{O}$ & $\mathbf{E}$ & $\mathbf{O}-\mathbf{E}$ & $(\mathbf{O}-\mathbf{E})^{2} / \mathbf{E}$ \\
\hline 4.39 & 2.6 & 1.79 & 1.23 \\
\hline 2.12 & 2.6 & -0.48 & 0.09 \\
\hline 2.09 & 2.6 & -0.51 & 0.10 \\
\hline 3.13 & 2.6 & -0.53 & 0.11 \\
\hline 4.30 & 2.6 & 1.70 & 1.11 \\
\hline 3.0 & 2.6 & 0.4 & 0.06 \\
\hline 3.19 & 2.6 & 0.59 & 0.13 \\
\hline 4.32 & 2.6 & 1.72 & 1.14 \\
\hline 3.09 & 2.6 & 0.49 & 0.09 \\
\hline 2.79 & 2.6 & 0.19 & 0.01 \\
\hline & & & $\mathbf{4 . 0 7}$ \\
\hline
\end{tabular}

Source: Extracted and computed from table 4

$\mathrm{fe}=25.91 / 10 \quad=\quad 2.6$

Degree of freedom $=(10-1)(2-1)=(9)(1)=9$

Tabulated value is 18.307 and the calculated value is 4.07 .

Therefore, since the tabulated value is greater than the calculated value, we accept the null hypothesis which says that the preventive measures on fraud mitigation have not been effective. This finding suggest that bank customers and banking public may lose confidence in the banks and if high rate of bank fraud mounts many affected banks begin to wind up. Thus, we strongly agree with Abiola and Oyewole (2013) that the principle of internal checks holds that no single official controls two or more functional responsibilities and that each officer should serve to check the other. There are still need for improving internal controls in the banks. The studied measures of controlling fraud generally revealed that collaboration with external persons is highly important if improved effectiveness of those techniques will be realized.

\section{Summary of Findings, Conclusion And Recommendations}

Summary of findings:This work has significantly shown that Bank managers are significant perpetrators of fraud in banks; the banks internal control techniques are not very effective as expected by the participants; the preventive measures for mitigating bank fraud have not also been very effective. The result also showed that the banks' internal control techniques have not been very effective and such ineffectiveness will lead to loss of public confidence as well as high rate of bank fraud which can lead to the winding up of the banks.Also, the preventive measures for mitigating bank fraud also have not been effective, though they might be efficient. This means that it might be part of their rules but they fail to implement them adequately.

Conclusion:Bank frauds are now becoming a global phenomenon. Fraud general inflicts untold hardship on bank owners, customers and their family members, as most bank failures are associated with large scale frauds. The prevention and detection of frauds are basically the responsibility of the management rather than the mere establishment of an effective and efficient internal control system. Human beings make the rules and apply the rules. Integrity therefore is required of bank managers. Trust and power should not be concentrated in the hands of a single staff to help strengthen the character and resilience of the concerned managers of banks and avoid possible system failure.

Recommendations:The importance of internal control department/unit of any organization, especially banks cannot be overemphasized. Given that the lack of effective internal control system/techniques is the major cause of bank frauds, we recommend that the management of every bank should create and establish a standard internal control system, strong enough to stand against the wiles of fraud in order to promote continuity of operations of the banks. The structure should be such that can remain relevant long after the founding fathers and capable of been updated with emerging technology. Of course, every worthwhile internal security should be reviewed regularly and as the need arises.

Other recommendations based on the findings include:

1. There should an establishment of work ethics unit in all the Banks. The unit should observe the attitude of the staff towards work and their spending habit to check if the amount spent is in line with the income earned. The wanting staff should be counselled in first instance; and unrepentant staff should be punished according to the rules of engagement.

2. The bank management should not allow a staff to remain one duty post for a period above four years. Sudden and regular redeployment of staff irrespective of position should be the norm. Thus, excessive confidence in a staff say for reasons of ability to work with minimum supervision; and or due to relevant banking experience could degenerate into a situation that could lead to committing fraud.

3. The bank staff should be mandatorily required to proceed on annual leave. Situations for accumulated leave should be exception and not the rule. This will reduce excessive confidence on a particular staff that may induce or allow room for fraudulent behavior. 
4. The reward system should tend preference for level of work done. And, the staff should be rewarded by making deserving long-service staff shareholders of the bank. This makes them owners, and properly to protect the bank's wealth and expose fraudulent tendencies.

5. Continuous retreat should organized for staff wherein emphasis should be on leadership by example and updating on technology. Leadership by example has always been the ideal good management practice. The management by example, should be the watch word of every banker, be it director, manager, officer or messenger. Everyone should comply with the laid down policies and procedures in the performance of any banking function.

\section{References}

[1]. Adeduro, A.A. (1998). An Investigation into Frauds in Banks.An Unpublished Thesis ofFaculty of Social Science, Department of Accounting, University of Lagos, $42-49$.

[2]. Adeleke, B.A. (1996). The Auditors Role and Responsibility in Relations to Fraud.The Nigerian Accountant (ICAN), 29(3), 30-45.

[3]. Adenibiya, P. (1999). The Internal Audit Function and Fraud: A Nigeria Case Study.ICAN News, January/March, 15-19.

[4]. Arens, A.\&Loebbecke, G.S. (1997). Audition An Integrated Approach, ( $7^{\text {th }}$ Ed). USA: Prentice-Hall.

[5]. Asukwo, P.E. (1999). Bank Frauds: A Look at the Nigerian Banking Clearing System, ICAN News, January/March Pp 19-24.

[6]. Bank Administration Institute (1989). Frauds Prevention and Detection Series. Chicago: The First National Bank of Chicago).

[7]. Benjamin, J. (2001). Internal Control and Fraud Prevention: The Account's Perspective. Accountancy News Publication, Training Arm of ANAN Jos, 5(1): 67-75.

[8]. Chizea, B. (1991). Frauds in the Banking Industry.Journal of the Chartered Institute of Bankers of Nigeria, 31,45-50.

[9]. Committee of Sponsoring Organizations of the Tread way Commission on Internal Control and Integrated Framework (COSO)(ICIF), 1994. http://www.cpa2biz.com/ast/main/cpa2biz_primary /internalcontrols/coso/prdovr-pc-990009/pc-990009.jsp Retrieved June 8, 2015.

[10]. Dinapoli, T.P. (2006). Standards of Internal Control in New York State Government. www.d/newyorkstatecomptroller.htm.

[11]. Encyclopedia Britannica (2009). http://www.britannica.com/ebchecked/topic/217591/fruad. Retrieved April 01,2010.

[12]. Ewa, H.D. \&Udoayang, T.Y. (2012). The Impact of Internal Control Design on Banks. Ability to Investigate Staff Fraud, and Life Style and Fraud Detection in Nigeria.International Journal of Research on Economics and Social Sciences, 2(2), 32-43.

[13]. Frazier, S.I. (1996). The New SAS No: 78, CPA Journal, 66(5).

[14]. Gold, S. (2009). By Starts Switch Board Anti-Hacking Investigation.Newsbytes, http://www.infowar.com/Accessed On 15/6/2015.

[15]. Grant, T. (2009). Guidance on Monitoring Internal Control Systems. Durham: COSO.

[16]. Hermanson, S. \& Stephens, H. (2012). How effective are the Organizations' Internal Controls? Insight into Specific Internal Control Elements.American Accounting Association, A31-A50.

[17]. Idolor, E.J. (2010). Bank Fraud in Nigeria: Underlying Cause, Efforts and Possible Remedies: African Journal of Accountancy, Economic, Finance and Banking Research, 6(6), 62-78.

[18]. Idowu, I. (2009). An Assessment of Fraud and its Management in Nigeria. Commercial Banks. European Journal of Social Science, $10(4), 628-640$

[19]. Izedonmi, O.I. (2000). Introduction to Auditing.Lagos: Ambik Press, Pp 156-158.

[20]. Jat, R.B. (1992). Internal Control and Fraud Prevention in Commercial Banks. An Unpublished MBA Thesis, Department of Management Sciences, University of Nigeria, Nsukka.

[21]. Jenfa, B.I. (1991). Internal Control and Fraud Prevention: The Accountants' Perspective. Accountancy News, 5(1), 32- 43.

[22]. Mahdi, S. \&Zhila, A. (2008). Fraud Detection and Audit Expectation Gap.International Journal of Business and Management, $3(10), 65-77$

[23]. Mcshane, L.S. (2007). Organizational Behavior (Essentials). Boston: McGraw-Hill Trwuinles_21. http://www.obessentials.com , 19-23.

[24]. Nigeria Deposit Insurance Corporation (NDIC) (2005). Annual Report and Statement of Account, NDIC, Abuja and Lagos, 10-18.

[25]. Nwankwo, G.O. (1991). Bank Management Principles and Practices. Lagos: Maltose House Press Ltd.

[26]. Ojo, O. (2008). Effect of Bank Frauds on Banking Operations in Nigeria. International Journal of Investment and Finance, 1(1), $103-123$

[27]. Ola, C.S. (2001). Questions and Answers on Cooperate Finance Financial Strategy, Creation and Auditing. Lagos: CSS Ltd.

[28]. Omachonu, J. \&Ndulor, T. (1998). Banks Fraud Shrinks in Number, Billons in Loot.The Guardian Newspaper, July 15, Lagos.

[29]. Spira, L.F.\& Page, M. (2003). Risk Management: The Reinvention of Internal Control and the Changing Role of Internal Audit Accounting. Auditing and Accountability Journal, 16(4), 640-661.

[30]. Wee, G. (2009). Audit Committee, Board of Directors, and Remediation of Maternal Weaknesses in Internal Control. Contemporary Accounting Research, 26(2), 549-579. 